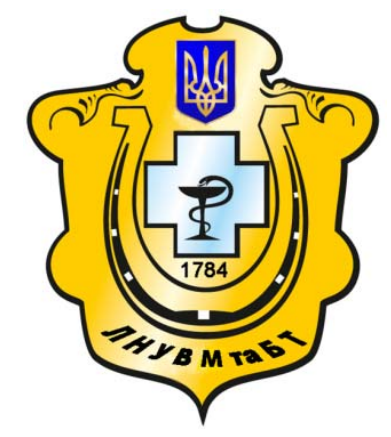

Науковий вісник Львівського національного університету ветеринарної медицини та біотехнологій імені С.З. Гжицького

Scientific Messenger of Lviv National University of Veterinary Medicine and Biotechnologies named after S.Z. Gzhytskyj

doi:10.15421/nvlvet7603

ISSN 2519-2701 print

ISSN 2518-1327 online

http://nvlvet.com.ua/

\title{
УДК330.4.658.8
}

\section{Маркетингове управління методами економіко-математичного моделювання}

\author{
T.I. Бурцева, Т.А. Пальонна, А.О. Боковня \\ kbti@ukr.net, tansha@ukr.net,7angela7@rambler.ru \\ Черкаський державний технологічний університет, \\ бульвар Шевченка, 460, Черкаси, 18000, Україна
}

\begin{abstract}
В статті наголошено, щуо маркетинг є одним з основних напрямів сучасного підприємництва, вказано на зростання ролі маркетингу в управлінні підприємствами та на необхідність забезпечення маркетингового управління ефективними методами. Наголошено на важливості методу математичного моделювання в маркетинговому управлінні, в забезпеченні прийняття управлінських рішень та вирішенні задач маркетингу. Проведено аналіз основних методів економікоматематичного моделювання та вказано напрямки їх використання в маркетинговому управлінні підприсмством, в підвищенні якості та ефективності діяльності маркетингових служб. Показано, щьо застосування економіко-математичних моделей вказує шляхи вдосконалення маркетингової інформаџії, веде до спрощення розв'язку системи задач планування й управління, інтенсифікації, підвищення точності розрахунків, оптимізачії та прогнозування. Вони дають можливість оцінити перспективи розвитку місткості ринку, визначити найбільш раціональні стратегії маркетингу і можливі відповідні кроки конкурентів, оцінити оптимальні затрати на маркетинг для отримання необхідного розміру прибутку.

Ключові слова: маркетинг, маркетингове управління, підприсмство, аналіз, планування, модель, метод, моделювання, економіко-математичне моделювання, математичні методи, оптимізація, прогнозування, прийняття управлінських рішень.
\end{abstract}

\section{Маркетинговое управление методами экономико-математического моделирования}

\author{
Т.И. Бурцева, Т.А. Пальонна, А.О. Боковня \\ kbti@ukr.net, tansha@ukr.net,7angela7@rambler.ru \\ Черкасский государственный технологический университет, \\ бульвар Шевченка, 460, Черкассы, 18000, Украина
}

\begin{abstract}
В статье отмечается, что маркетинг является одним из основных направлений современного предпринимательства, указано на рост роли маркетинга в управлении предприятиями и на необходимость обеспечения маркетингового управления эффективными методами. Отмечена важность метода математического моделирования в маркетинговом управлении, в обеспечении принятия управленческих решений и решении задач маркетинга. Проведен анализ основных методов экономико-математического моделирования и указаны направления их использования в маркетинговом управлении предприятием, повышении качества и эффективности деятельности маркетинговых служб. Показано, что применение экономико-математических моделей указывает пути совершенствования маркетинговой информации, ведет к упрощению решения системы задач планирования и управления, интенсификации, повышения точности расчетов, оптимизачии и прогнозирования. Они дают возможность оценить перспективы развития емкости рынка, определить наиболее рациональные стратегии маркетинга и возможные ответные шаги конкурентов, оценить оптимальные затраты на маркетинг для получения необходимого размера прибыли.
\end{abstract}

Citation:

Burceva, T.I., Palonna, T.A., Bokovnya, A.O. (2017). Marketing management of economic-mathematical modeling methods. Scientific Messenger LNUVMBT named after S.Z. Gzhytskyj, 19(76), 15-18. 
Ключевые слова: маркетинг, маркетинговое управление, предприятие, анализ, планирование, модель, метод, моделирование, экономико-математическое моделирование, математические методы, оптимизация, прогнозирование, принятие управленческих решений.

\title{
Marketing management of economic-mathematical modeling methods
}

\author{
T.I. Burceva, T.A. Palonna, A.O. Bokovnya \\ kbti@ukr.net, tansha@ukr.net,7angela7@rambler.ru \\ Cherkasy State Technological University \\ Shevchenko Boulevard, 460, Cherkasy, 18000, Ukraine
}

\begin{abstract}
The article noted that marketing is one of the main areas of modern business. The growing role of marketing in the enterprises management and the necessity to ensure effective methods of marketing management were stated. The importance of mathematical modeling in marketing management, to ensure the management decisions and solving problems of marketing was emphasized. The analysis of the main methods of economic-mathematical modeling and directions for their use in marketing management of enterprises to improve the quality and efficiency of marketing services were given. They make it possible to assess the prospects of market size, to determine the most rational marketing strategy and appropriate steps of possible competitors, to estimate the optimum marketing costs needed to get the profit.

For large-scale implementation in enterprises of modern economic and mathematical modeling methods of marketing situations needed a way to implement the results of marketing analysis. Therefore, it Aktual scientific challengefavor the development and implementation of modern software to solve complexproblems of basic marketing information system

Key words: marketing, marketing management, enterprise analysis, planning model, method, simulation, economic and mathematical modeling, mathematical methods, optimization, forecasting, decision-making.
\end{abstract}

\section{Ветуп}

В умовах ринкової економіки маркетинг є одним 3 основних напрямів сучасного підприємництва i займає особливе місце в повсякденній роботі підприємств, фірм, компаній. Сьогодні для більшості вітчизняних підприємств маркетингове управління стає однією з умов виживання та успішного функціонування. Важливими методами забезпечення ефективності проведення маркетингового управління $є$ методи економіко-математичного моделювання.

Вивченню проблем застосування методів економіко-математичного моделювання в маркетинговому управлінні діяльністю підприємства приділяється значна увага в економічній науці та практиці. Цим питанням присвятили праці вітчизняні та зарубіжні вчені: В.В. Вітлінський, В.Г. Воронкова, С.С. Гаркавенко, Л.Ф. Сжова, В.В. Здрок, М.П. Калиниченко, Т.I. Макаренко, С.I. Наконечний, С.В. Прокопов, М.О. Турченюк. В той же час постійні проблеми сучасного ринку вимагають пошуку, вивчення та удосконалення методів маркетингового управління та заходів його реалізації.

Мета $і$ завдання дослідження. Стаття присвячена дослідженню ролі економіко-математичного моделювання в маркетинговому управлінні підприємством. Щоб досягти поставленої мети, треба дослідити використання математики як методу вдосконалення маркетингового управління та показати можливості, які можна отримати за допомогою економікоматематичного моделювання.

\section{Матеріал і методи досліджень}

Останнім часом в економіці України спостерігається зростання ролі маркетингу в управлінні підприємствами. Маркетинг вчить визначати потреби ринку та якнайкраще їх задовольняти - i не лише відносно виробництва якісного товару, а й стосовно зручності його придбання, обслуговування тощо (Voronkova, 2008). Тобто маркетинг - це ринкова концепція управління діяльністю організації, яка спрямована на вивчення ринку, конкретних запитів споживачів i орієнтацію на них пропонованих товарів і послуг, а також на формування та стимулювання купівельного попиту 3 метою збільшення продажів, завоювання необхідної частки на ринку та збільшення прибутків підприємства (Harkavenko, 2006).

Основна мета сучасного маркетингу - досягнення стратегічних цілей функціонування підприємства на основі постійного дослідження та максимального задоволення потреб споживачів і суспільства в цілому. Відповідно до цього маркетингове управління включає такі основні функції: аналіз, планування, організацію, мотивацію, реалізацію, контроль.

Для вирішення цих функцій як необхідний і потужний інструмент широко використовуються математичні моделі та методи. Використання математичних методів у сфері маркетингового управління - важливий напрям удосконалення системи маркетингу. Застосування математичного моделювання сприяє підвищенню якості та ефективності діяльності маркетингових служб організацій і фірм, а також безпосередньо процесу управління.

Математичні моделі надзвичайно різноманітні за природою досліджуваної системи, за завданнями дослідження та формами математичних залежностей. За типом задач, які розв'язуються в маркетинговому управлінні, можна виділити такі основні напрямки використання економіко-математичного моделювання:

- оптимізація планування за допомогою оптимізаційних моделей;

- прогнозування та вибір перспективних напрямків стратегії діяльності підприємства; 
- прийняття управлінських рішень за допомогою методів експертних оцінок;

- здійснення кількісного аналізу виробництва і використання виробничих потужностей на основі балансових математичних моделей.

В маркетингу набули широкого застосування оптимізаційні методи як засіб вирішення задач оптимізації виробничо-господарської діяльності. Вони дозволяють знаходити оптимальний 3 позиції певного критерію варіант використання ресурсів. Цінність їх для маркетингового управління полягає у тому, що вони дають змогу оцінювати досягнення потенціалу, планових завдань, визначати стан устаткування, обмежені види сировини і матеріалів, ступінь конкурентності та дефіцитності. Економіко-математичні моделі оптимізації містять цільову функцію, основою якої $\epsilon$ ефективність виробництва, і систему обмежень, куди входять чинники, у сфері яких модель не втрачає своєї практичної цінності. Вирішення задачі називається оптимальним рішенням, або оптимальним планом. Прикладом оптимізаційних математичних моделей $є$ задачі оптимального розподілу ресурсів, капітальних вкладень, оптимального керування запасами та iн.

До оптимізаційних математичних моделей відноситься також задача про оптимальне закріплення постачальників за споживачами, так звана транспортна задача. Суть іiі полягає в тому, що запаси деякого продукту $є$ на кількох пунктах постачання і цей продукт потрібно доставити в кілька пунктів споживання. Потрібно визначити, яку кількість продукту треба перевезти з кожного пункту постачання до кожного пункту споживання так, щоб забезпечити вивезення всього наявного продукту з пунктів постачання, задовольнивши повністю потреби кожного пункту споживання, і при цьому сумарна вартість перевезень була б мінімальною.

У практичній діяльності організації і служб маркетингу використовуються системи регулювання товарних запасів, засновані на різних стратегіях поповнення запасів, тобто на певних правилах цього поповнення. Для вирішення таких задач використовують методи і моделі управління товарними запасами, що є одним з видів оптимізаційних задач

Часто в маркетингу виникають задачі, в яких доводиться приймати рішення в ситуаціях 3 кількома учасниками, коли значення цільової функції для кожного учасника залежить також і від рішень, прийнятих іншими учасниками. Тоді для прийняття управлінських рішень варто використовувати методи теорії ігор. Теорія ігор - це сукупність математичних методів і моделей, пов'язаних із прийняттям раціональних рішень в умовах конфлікту та невизначеності.

Для ефективного маркетингового управління підприємства важливою складовою є узгоджене планування усіх підрозділів підприємства. При плануванні та організації виробничого процесу використовують сіткове планування. Таке планування дозволяє побудувати єдиний ланцюг, що пов'язує виробничий процес $з$ доставкою готової продукції, шляхом побудови графоаналітичної моделі. Сіткові графіки дають можливість легше аналізувати правильність організації виробничих процесів, контролювати хід їх виконання, виявляти недоліки і своєчасно їх ліквідовувати, перерозподіляючи матеріальні й трудові ресурси підприємства.

За допомогою математичних методів можна досліджувати також кількісні оцінки процесів масового обслуговування. Будь-яке підприємство та його підрозділи можна представити як об'єкт системи обслуговування, і теорія масового обслуговування широко використовує математичні методи.

В останні роки для прийняття управлінських рішень в комплексі 3 математичним моделюванням часто застосовують методи експертних оцінок. Ці методи побудовані на використанні професійного досвіду та інтуїції спеціалістів при розв'язуванні аналітичних задач, особливо при прогнозуванні розвитку економічних ситуацій.

Для вибору ефективних варіантів управління підприємством, його раціональної маркетингової діяльності необхідно прогнозувати можливі ситуації, впливати на них, вибираючи оптимальні варіанти рішень, спрямовувати його господарську діяльність на досягнення поставленої мети (Turchenyuk and Shvets', 2011).

Маркетингові дослідження дають змогу прогнозувати попит, виявляти пріоритетні галузі, сфери діяльності та створювати відповідну основу для формування інвестиційної політики (Voronkova, 2008).

В економіці, як правило, не існує суворих функціональних залежностей. На рівень економічних показників впливає багато факторів як закономірних, так і випадкових, причому деякі фактори не можуть бути виражені кількісно, а про інші неможливо отримати інформацію. Тому метод моделювання, який використовується для прогнозування економічних показників, базується головним чином на стохастичних моделях, які реалізуються на основі статистичної інформації. Моделі такого виду носять назву економетричних. Економетричні методи $\epsilon$ своєрідним поєднанням трьох сфер знань: економіки, математики і статистики. Вони дають можливість з урахуванням наявних факторів внутрішнього i зовнішнього середовища оцінити перспективи розвитку місткості ринку визначити найбільш раціональні стратегії маркетингу і можливі відповідні кроки конкурентів, оцінити оптимальні затрати на маркетинг для отримання максимального прибутку.

Основою економетрії $є$ економічна модель, під якою розуміють схематичне подання економічного явища чи процесу за допомогою математичного виразу (формули), що відображає зв'язок досліджуваного показника і факторів, які його визначають.

При економіко-математичному моделюванні маркетингових задач досить часто використовують балансові моделі. В основі створення таких моделей лежить балансовий метод, тобто взаємне зіставлення необхідних матеріальних, трудових і фінансових ресурсів. Балансова модель - це система рівнянь, кожне 3 яких виражає баланс між кількістю продукції, що виробляється окремими економічними об'єктами, i сукупною потребою в цій продукції. 


\section{Результати та їх обговорення}

За допомогою математичних моделей відбувається удосконалення системи маркетингової інформації шляхом її впорядкування, виявлення недоліків, вироблення вимог для підготовки нової інформації або іiї коригування. Широке використання економікоматематичних методів $є$ важливим напрямком удосконалення шляхів вирішення проблем маркетингового управління, що підвищує ефективність діяльності підприємства загалом.

\section{Висновки}

Отже, економіко-математичні методи відіграють важливу роль у вирішенні проблем маркетингу. Математичне моделювання $\epsilon$ універсальним інструментом аналізу й дослідження виробничих та господарських процесів і явищ (Kalynychenko, 2013). Вони вказують шляхи вдосконалення економічної інформації, сприяють спрощеному розв'язанню системи задач маркетингу, задач планування й управління, інтенсифікації і підвищенню точності економічних розрахунків.

Перспективи подальших досліджень. Для масштабного впровадження на підприємствах сучасних економіко-математичних методів моделювання маркети- нгових ситуацій необхідний спосіб реалізації результатів маркетингового аналізу. Тому актуальним науковим завданням виступає розробка та впровадження сучасного програмного забезпечення для вирішення комплексу основних задач маркетингової інформаційної системи (Yarenko, 2009).

\section{Бібліографічні посилання}

Harkavenko, S.S. (2006). Marketynh: Pidruchnyk. K.: Libra (in Ukrainian).

Kalynychenko, M.P. (2013). Optymizatsiyni modeli pryynyattya marketynhovykh rishen'. Elektronne naukove fakhove vydannya «Efektyvna ekonomika». 7 (in Ukrainian).

Voronkova, V.H. (2008). Marketynh sotsial'nykh posluh: navchal'nyy posibnyk dlya stud. Vuziv. Kyyiv: Profesional (in Ukrainian).

Turchenyuk, M.O., Shvets', M.D. (2011). Marketynh: pidruchnyk. K.: Znannya (in Ukrainian).

Yarenko, A.V. (2009). Vykorystannya prykladnykh komp"yuternykh prohram pry vyvchenni profesiynykh marketynhovykh dystsyplin. Visnyk Khmel'nyts'koho natsional'noho universytetu. 5(3), 238-241 (in Ukrainian).

Стаття надійшла до редакиії 1.03.2017 